Japan. J. Med. Sci. Biol., 40, 171-174, 1987.

\title{
PREVALENCE OF HEPATITIS B MARKERS, ANTIBODIES TO ADULT T CELL LEUKEMIA/LYMPHOMA VIRUS AND ANTIBODIES TO HUMAN IMMUNE DEFICIENCY VIRUS IN PROSTITUTES IN FUKUOKA, JAPAN
}

Shin-ichi YOSHIDA, Yasuo MIZUGUCHI, Kumiko MIZUE, Hisahiro SAKAMOTO1 and Shinji URABE2

Department of Microbiology, School of Medicine, and 1Blood Transfusion Service, University of Occupational and Environmental Health, Yahatanishi-ku, Kitakyushu 807 and 2Urabe Hospital, Nishinakasu 6-20, Fukuoka 810, Japan

(Received November 24, 1987. Accepted March 24, 1988)

SUMMARY: Prevalence of hepatitis B (HB) markers, antibodies to human T cell leukemia virus (HTLV-1) and antibodies to human immune deficiency virus 1 (HIV-1) in prostitutes working in Fukuoka city were studied. Sera were collected from 237 prostitutes during January-September, 1986. Among them, 9 (3.8\%) were $\mathrm{HB}$ virus surface-antigen ( $\mathrm{HBs} \mathrm{Ag}$ ) positive, of whom, 3 were $\mathrm{HBe}$ antigen positive and the remaining 6 were anti-HBe positive. The positive rate of anti-HBs was $34.2 \%$. The incidence of anti-HTLV-1 in the prostitutes was $5.9 \%$. These incidences are considered to be within the usual range in Kyushu district. No seropositive case for anti-HIV was found.

\section{INTRODUCTION}

It is acknowledged that prostitutes working at massage parlors are important in the dissemination of sexually transmitted diseases. We have reported that prostitutes are important in the transmission of gonorrhoea in Fukuoka, Japan (1).

吉田真一·水口康雄·水江久美子(産業医科大学微生物学教室 北九州市八幡西区医生ヶ 丘1-1)

坂本久浩(産業医科大学病院輸血部)

占部慎二(占部病院 福岡市西中州6-20) 
Some viral diseases, such as hepatitis B (HB), adult $\mathrm{T}$ cell leukemia/lymphoma (ATLL) and acquired immune deficiency syndrome (AIDS) are known to be transmitted by sexual contact in addition to the blood transfusion (2,3). Among these diseases, HB and ATLL are endemic in Kyushu district including Fukuoka $(4,5)$. No sufficient data, however, on the incidence of HB and ATLL markers in the prostitutes have been compiled. We, therefore, conducted studies of prostitutes in Fukuoka city with the objective of determining the prevalence of these viral diseases.

\section{MATERIALS AND METHODS}

Sera were obtained from 237 female prostitutes attending Urabe Hospital in Fukuoka city from January to September, 1986. All sera were stored frozen at $-80 \mathrm{C}$ until use. Age distribution of the prostitutes was as follows: $<20,4.2 \% ; 20-$ $29,71.3 \% ; 30-39,24.5 \%$. It was impossible to identify their birth places.

$\mathrm{HB}$ virus-surface antigen ( $\mathrm{HBs} \mathrm{Ag}$ ) and antibody to $\mathrm{HBs}$ (anti-HBs) were measured by enzyme immunoassay (EIA) using Hepanostika HBs (Organon Teknika, Tokyo). $\mathrm{HBe} \mathrm{Ag}$ and anti-HBe antibody were detected by radioimmunoassay (Abott Lab., North Chicago, IL). Antibody to human T cell leukemia virus-1 (HTLV-1) was measured by the particle agglutination method using antigen-coated gelatin particle (Serodia-ATLA, Fujirebio, Tokyo). Antibody to human immune deficiency virus-1 (HIV-1) was determined by EIA using Vironostika anti-HIV (Organon Teknika). Cut off values were determined according to the specification of each kit.

\section{RESULTS AND DISCUSSION}

The results are summarized in Table I. Among 237 prostitutes in Fukuoka city, 9 (3.8\%) were $\mathrm{HBs} \mathrm{Ag}$ positive, of whom, 3 were $\mathrm{HBe}-\mathrm{Ag}$ positive and remaining 6 were anti-HBe positive. The positive rate of anti-HBs was $34.2 \%$. Age specific prevalence of anti-HBs was $20 \%$ among the age group under $20,31.2 \%$ in 20-29 years, and $43.1 \%$ in over 30 years of age, respectively.

Kashiwagi and Kaji (4) reported that the incidences of $\mathrm{HBs} \mathrm{Ag}$ and anti-HBs in overall population of Kyushu district in 1967-1975 were 2.7\% and 25\%, and that of Fukuoka city were $3.6 \%$ and $17.6 \%$, respectively. They showed also that the incidence of anti-HBs in normal woman population in Kyushu district, to which Fukuoka Prefecture belongs, was $30.6 \%$ and it was significantly higher than that 
Table I. Prevalence of hepatitis B, HTLV-1 and HIV-1 markers in 237 prostitutes in Fukuoka, Japan, during January-September, 1986

\begin{tabular}{lcr}
\hline \multicolumn{1}{c}{ Markers } & $\begin{array}{c}\text { Number of } \\
\text { prostitutes }\end{array}$ & $(\%)$ \\
\hline HBs Ag & 9 & $(3.8)$ \\
Anti-HBs & 81 & $(34.2)$ \\
Anti-HTLV-1 & 14 & $(5.9)$ \\
Anti-HIV-1 & 0 & $(0.0)$ \\
\hline
\end{tabular}

of male population. In a separate study, Kashiwagi et al. (6) analyzed also the agespecific prevalence of HB markers among healthy subjects in Kyushu in 1979-1981 and reported that the incidences of anti-HBs was $10.1 \%$ in age group 19-10, $18.3 \%$ in age group 29-20, and $30.7 \%$ in age group 39-30, respectively. In the case of anti$\mathrm{HBs}$, only the age group of over 30 years in the prostitutes showed a significantly higher rate than that of healthy subjects ( $<<0.01$, Chi-square test). These data suggested that the incidence of $\mathrm{HBs} \mathrm{Ag}$ and anti-HBs in the prostitutes is not necessarily high, being rather contradictory to the data reported by Goh et al. (2) who showed that both $\mathrm{HBs} \mathrm{Ag}$ and anti-HBs in prostitutes were significantly higher than normal population in Singapore.

The incidence of anti-HTLV-1 in the prostitutes in Fukuoka city was 5.9\% which is also within the usual range of Kyushu district. The prevalence rate of anti-HTLV-1 in Kyushu is highest in Japan ranging from 3 to about $30 \%$ (mean 8.0\%); that in other districts is much lower (1.2-0.3\%) (5).

No seropositive case for anti-HIV-1 was found among the prostitutes, indicating that AIDs is not endemic among them. The total numbers of anti-HIV1 positive cases and patients with AIDs in Japan (November, 1987) have been reported to be 986 and 59, respectively (data from Ministry of Health and Welfare). 


\section{REFERENCES}

1. Urabe, S., Yoshida, S. and Mizuguchi, Y. (1983): Brit. J. Vener. Dis., 59, $37-$ 40.

2 Nakano, S., Ando, Y., Ichijo, M., Moriyama, I., Saito, S., Sugiyama, K. and Hinuma, Y. (1984): Gann, 75, 1044-1045.

3. Goh, C. L., Kamarudin, A., Chan, S. H. and Rajan, V. S. (1985): Genitourin. Med., 61, 127-129.

4. Kashiwagi, S. and Kaji, M. (1976): J. Japan. Assoc. Infect. Dis., 50, 387-396 (in Japanese).

5. Maeda, Y., Fukukawa, M., Takehara, Y., Yoshimura, K., Miyamoto, K., Matsuura, T., Morishima, Y., Tajima, K., Okochi, K. and Hinuma, Y. (1984): Int. J. Cancer, 33, 717-720.

6. Kashiwagi, S., Hayashi, J., Ikematsu, H., Nomura, H., Kusaba, T., Shingu, T., Hayashida, K. and Kaji, M. (1983): Amer. J. Epidemiol., 118, 787-794. 